Indonesian Journal of Medicine (2019), 4(3): 252-258

https://doi.org/10.26911/theijmed.2019.04.03.08

\title{
Path Analysis of the Effect of Waist-Pelvic Circumference, Body Mass Index, and Abdominal Circumference on the Occurrence of Prediabetes
}

\author{
Cindy Lestyani Loekito'), Bhisma Murti²), Eti Poncorini Pamungkasari3) \\ ${ }^{1)}$ Masters Program in Nutrition, Universitas Sebelas Maret \\ 2)Masters Program in Public Health, Universitas Sebelas Maret \\ 3)Faculty of Medicine, Universitas Sebelas Maret
}

\begin{abstract}
Background: Diabetes mellitus is an important health problem in the world. Pre-diabetes is a state of blood sugar levels above normal but below the criteria for diabetes. American Diabetes Association (ADA) uses criteria for hemoglobin $\mathrm{A1C}$ (HbA1C) levels of 5.7\% to $6.4 \%$ to define prediabetes. The prevalence of pre-diabetes was the highest in overweight individuals. In many studies, body fat levels were assessed by indicators of waist-pelvic circumference, abdominal circumference, and BMI. Among the three, it is still a debate which is more influential on the condition of pre-diabetes. The purpose of this study was to determine the effects of waist-pelvic circumference, BMI, and abdominal circumference in pre-diabetes.

Subjects and Method: A cross sectional study was conducted at Prodia Clinic, Surakarta, Central Java, from January to March 2019. A sample of 200 study subjects was selected by fixed disease sampling. The dependent variable was pre-diabetes. The independent variables were waist-pelvic circumference, BMI, and abdominal circumference. The data on HbA1C were measured by NGSP standardized ion exchange HPLC method. The data were analyzed by path analysis.

Results: Abdominal circumference $>90 \mathrm{~cm}$ in men and $>80 \mathrm{~cm}$ in women $(\mathrm{b}=0.87 ; 95 \% \mathrm{CI}=0.23$ to $1.51 ; \mathrm{p}=0.008)$ and age $\geq 45$ years old $(\mathrm{b}=1.70 ; 95 \% \mathrm{CI}=0.93$ to $2.46 ; \mathrm{p}<0.001)$ were directly increased pre-diabetes. Pre-diabetes was indirectly affected by waist-pelvic circumference, gender, and obesity.

Conclusions: Abdominal circumference $>90 \mathrm{~cm}$ in men and $>80 \mathrm{~cm}$ in women and age $\geq 45$ years old are directly increased pre-diabetes. Pre-diabetes is indirectly affected by waist-pelvic circumference, gender, and obesity.
\end{abstract}

Keywords: prediabetes, abdominal circumference, waist-pelvic circumference, body mass index

\section{Correspondence:}

Cindy Lestyani Loekito. Masters Program in Nutrition, Universitas Sebelas Maret. Jl. Ir. Sutami 36A, Surakarta 57126, Central Java. Email: cindy.l.1@student.uns.ac.id. Mobile:o82134424950.

\section{BACKGROUND}

Diabetes mellitus was an important health problem in the world. The prevalence of pre-diabetes was increasing throughout the world so it is estimated that by 2030 more than 470 million people will become prediabetes (Tabák et al., 2012). In Indonesia, the prevalence of pre-diabetes reached 10\% (Soewondo and Pramono, 2011).

A person with a prdiabetes can become DM within 10 years if they do not change their lifestyles. Interventions with losing weight, regulating diet and increasing physical activity can reduce risk by 58\% (Compánán-Ortiz et al., 2018)

The American Diabetes Association (2019) uses the criteria of fasting blood sugar 100 to $125 \mathrm{mg} / \mathrm{dl}$ and post prandial 2 hour blood sugar 140 to $200 \mathrm{mg} / \mathrm{dl}$, or hemoglobin A1c (HbA1C) levels 5.7\% to $6.4 \%$ for define pre-diabetes. $\mathrm{HbA1C}$ can be used to predict pre-diabetes with the same 
predictive value as GDP and GD2PP (Vijayakumar et al., 2017). Studies on prediabetes in Indonesia using $\mathrm{HbA1C}$ are still limited.

Along with the increaseof body mass index becoming abnormal, abdominal circumference and the ratio of hip waist circumference to the risk of type $2 \mathrm{DM}$ increase, and when abdominal circumference and the ratio of waist to hip return to normal DM risk also decreases (Yang et al., 2016). The prevalence of pre-diabetes is highest in overweight individuals, and increases in all BMI groups included in the normal BMI area. In many studies, body fat levels were assessed by indicators of waist hip ratio, abdominal circumference and the most common use of BMI (Czernichow et al., 2011). Based on this background, the purpose of this study was to determine the effect of waist-pelvic circumference, BMI and abdominal circumference in prediabetes.

\section{SUBJECTS AND METHOD \\ 1. Study Design \\ This was an analytic observational study with a cross sectional study approach. It was conducted at the Prodia Clinic in Sura- karta, Central Java, Indonesia for three months from January to March 2019.}

\section{Population and Samples}

The population in this study was patients who underwent $\mathrm{HbA1C}$ without a history of DM. A sample of 200 study subjects was selected by fixed disease sampling.

\section{Study Variables}

The dependent variable in this study was $\mathrm{HbA1C}$ levels. The independent variables of this study were body mass index, abdominal circumference, hip waist circumference, age, and gender.

\section{Operational Definition}

Pre-diabetes. Prediabetes was defined as a level of $\mathrm{HbA1C} 5.7$ to $6.4 \%$.
Age. Age was defined as the age of study subjects when measurements are based on date of birth.

Gender. Gender was defined based on the characteristics of men and women.

Body Mass Index. The body mass index was defined as the value obtained from the calculation between body weight $(\mathrm{kg})$ divided by the square of the height $\left(\mathrm{m}^{2}\right)$.

Abdominal circumference. The abdominal circumference was defined as the size of the body circumference in the middle between the rib cage which can be felt by the upper part of the iliac crest.

Waist-pelvic circumference. Waistpelvic circumference was defined as a comparison of waist circumference and hip circumference.

\section{Study Instruments}

The data were obtained using direct measurements with scales, microtoise, measurement tape, and questionnaire. Measurement of $\mathrm{HbA1C}$ levels were obtained using the NGSP standardized ion exchange HPLC method.

\section{Data Analysis}

Univariate analysis was used to show frequency distribution and percentage characteristics of research subjects. Bivariate analysis was done using chi square test. Multivariate analysis was performed using path analysis. Five steps of path analysis have been carried out, namely: model specifications, model identification, model suitability, parameter estimation, model specification.

\section{Research Ethics}

The research ethics included inform consent, anonymity, confidentiality, and research ethics. This study received ethical ethics from the Research Ethics Committee Faculty of Medicine, Universitas Sebelas Maret, Surakarta, with number 161/$\mathrm{UN27.06/KEPK/201.}$ 
Indonesian Journal of Medicine (2019), 4(3): 252-258

https://doi.org/10.26911/theijmed.2019.04.03.08

\section{RESULTS}

\section{Samples Characteristics}

The sample characteristics are illustrated in Table 1.

Table 1. Samples Characteristics

\begin{tabular}{llcc}
\hline & Characteristics & n & \% \\
\hline Gender & Female & 114 & 57 \\
& Male & 86 & 43 \\
Age & $\geq 45$ & 124 & 62 \\
& $<45$ & 76 & 38 \\
BMI & High $(\geq 25)$ & 98 & 49 \\
Abdominal circumference & Normal $(<25)$ & 102 & 51 \\
& High $($ men $>90$, women $>80)$ & 84 & 42 \\
Circular ratio & Normal $($ men $\leq 90$, women $\leq 80)$ & 116 & 58 \\
waist-hip & High $($ men $\geq 0.9$; women $\geq 0.85)$ & 90 & 45 \\
& Normal $($ men $<0.9 ;$ women $<0.85)$ & 110 & 55 \\
\hline
\end{tabular}

\section{Bivariate Analysis}

Bivariate analysis in table 2 shows the effect of age, gender, abdominal circumference, BMI, and waist-pelvic waist circumference on prediabetes. Age $\geq 45$ years (OR $=5.43, \mathrm{p}<0.001$ ), abdominal circumference $(\mathrm{OR}=2.36, \mathrm{p}=0.005)$, $\mathrm{BMI}(\mathrm{OR}=1.16, \mathrm{p}=0.617)$, waist-pelvic circumference $(\mathrm{OR}=1.87, \mathrm{p}=0.043)$ increased pre-diabetes. Female gender reduced the prevalence of pre-diabetes $(\mathrm{OR}=0.79, \mathrm{p}=0.426)$.

Table 2. Bivariate analysis

\begin{tabular}{|c|c|c|c|c|c|c|c|c|c|}
\hline \multirow{2}{*}{\multicolumn{2}{|c|}{ Independent variable }} & \multicolumn{4}{|c|}{ HbA1C } & \multirow{2}{*}{\multicolumn{2}{|c|}{ Total }} & \multirow{3}{*}{$\mathbf{O R}$} & \multirow{3}{*}{$\mathbf{p}$} \\
\hline & & \multicolumn{2}{|c|}{$<5.7 \%$} & \multicolumn{2}{|c|}{$\geq 5.7-6.4 \%$} & & & & \\
\hline & & $\mathbf{n}$ & $\%$ & $\mathbf{n}$ & $\%$ & $\mathbf{n}$ & $\%$ & & \\
\hline \multirow[t]{2}{*}{ Gender } & Female & 79 & 69.3 & 35 & 30.7 & 114 & 100 & 0.79 & 0.426 \\
\hline & Male & 55 & 64 & 31 & 36 & 86 & & & \\
\hline \multirow[t]{2}{*}{ Age } & $\geq 45$ & 68 & 54.8 & 56 & 45.2 & 124 & 100 & 5.43 & $<0.001$ \\
\hline & $<45$ & 66 & 86.8 & 10 & 13.2 & 76 & & & \\
\hline \multirow[t]{2}{*}{ BMI } & Overweight & 64 & $65 \cdot 3$ & 34 & 34.7 & 98 & 100 & 1.16 & 0.617 \\
\hline & Normal & 70 & 68.6 & 32 & 31.4 & 102 & & & \\
\hline Abdominal & High & 47 & 56 & 37 & 44 & 84 & 100 & 2.36 & 0.005 \\
\hline circumference & normal & 87 & 75 & 29 & 25 & 116 & & & \\
\hline Waist-pelvic & High & 67 & 60.9 & 43 & 39.1 & 90 & 100 & 1.87 & 0.043 \\
\hline circumference & Normal & 67 & 74.4 & 23 & 25.6 & 110 & & & \\
\hline
\end{tabular}

\section{Path Analysis}

Path analysis run on Stata 13 program. Table 3 described the results of pathway analysis in which abdominal circumference $>90 \mathrm{~cm}$ in men and $>80 \mathrm{~cm}$ in women had a direct positive effect on the risk of pre-diabetes.

The higher the abdominal circumference, the higher the risk of pre-diabetes, and it was statistically significant $(b=0.87$; CI95\% $=0.23$ to $1.51 ; \mathrm{p}=0.008$ ).
Age $\geq 45$ years had a direct positive effect on the risk of pre-diabetes. The older they get, the higher the risk of pre-diabetes, and it was statistically significant $(\mathrm{b}=1.70 ; 95 \% \mathrm{CI}=0.93$ to $2.46 ; \mathrm{p}<0.001)$. Waist-hip circumference ratio $\geq 0.9$ in men and $\geq 0.85$ in women, female gender and $\mathrm{BMI} \geq 25 \mathrm{~kg} / \mathrm{m}^{2}$ had an indirect positive relationship with pre-diabetes through abdominal circumference, which was statistically significant. 


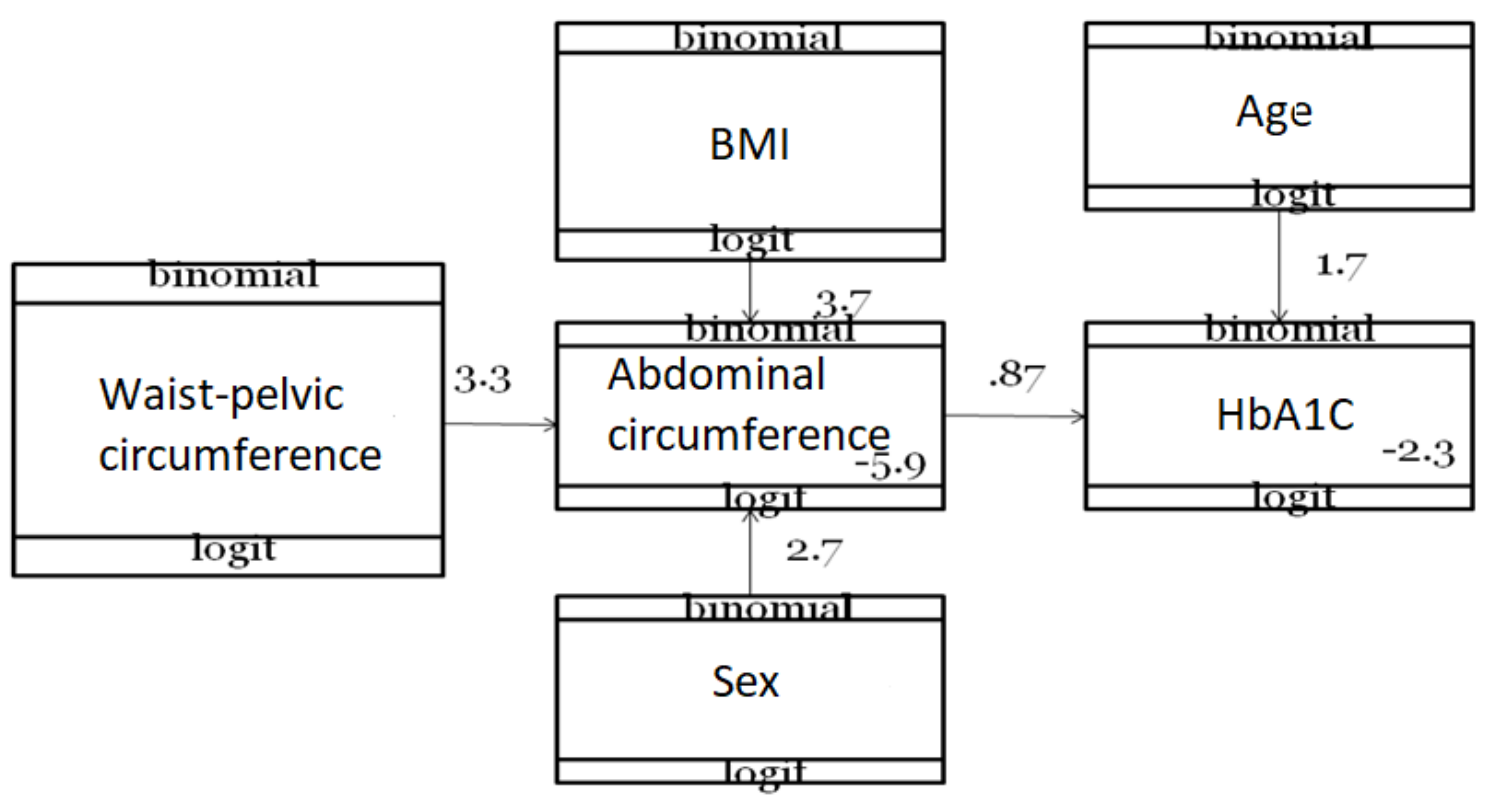

Figure 1. Path analysis model specifications

Table 3. The results of path analysis

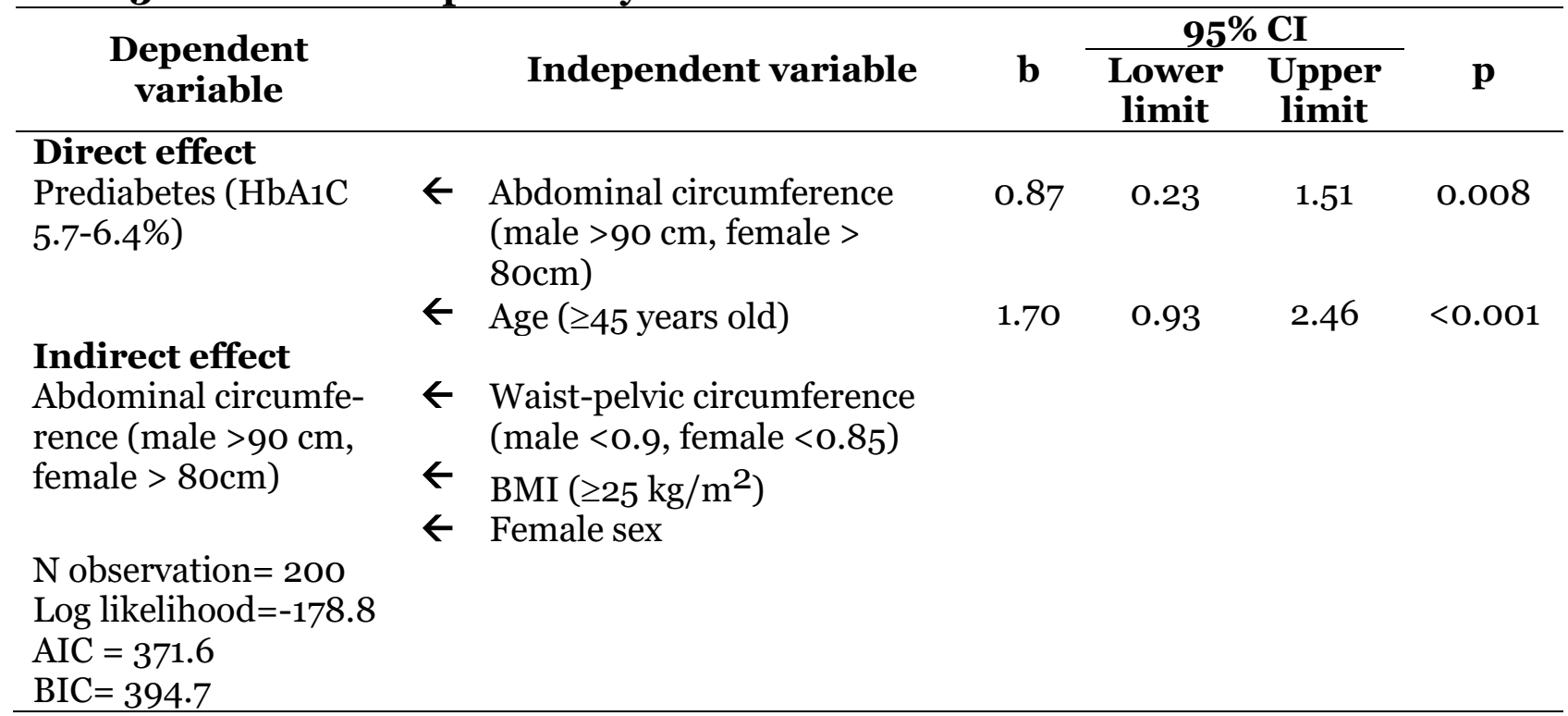

\section{DISCUSSION}

\section{The Effect of abdominal circumfe- rence on prediabetes}

Abdominal obesity in men and women has the strongest relationship with prediabetes (Díaz-Redondo et al., 2015). This was in accordance with the study of Luo et al. (2013) and Chen et al. (2015) study that showed changes in abdominal circumference were better at predicting the risk of type 2 DM. An increase in abdominal circumference reflected accumulation of adi- pose fat tissue which caused insulin resistance (Kashiwagi et al., 2017).

\section{The effect of age on prediabetes}

Fat percentage increases with age (Compánán-Ortiz et al., 2018). Pancreatic function, tissue sensitivity to insulin and insulin receptor activity decreases and muscle tissue decreases, consequently blood glucose increases so that $\mathrm{HbA1C}$ levels also increase (Pani et al., 2008). Secondary effects of body fat and physical fitness also occur with age (Yanai et al., 2018). 
Indonesian Journal of Medicine (2019), 4(3): 252-258

https://doi.org/10.26911/theijmed.2019.04.03.08

\section{The effect of waist-pelvic circumfe- rence, BMI, and gender on pre- diabetes through abdominal circumference}

In accordance with Abtahi et al. (2010) study which showed that a person with BMI, abdominal circumference and hip waist circumference ratio increased, the risk of pre-diabetes also increased. The hip waist circumference ratio was strongly associated with the risk of type 2 DM (Mansour and Al-Jazairi., 2007). The hip waist circumference ratio describes body fat distribution, but the abdominal circumference had a stronger relationship with metabolic and cardiovascular risk factors in accordance with a study conducted by Wahyuni and Murbawani (2016).

A study conducted in India also shows that BMI can be used to detect prediabetes early (Pandey et al., 2017). BMI is associated with body fat percentage, while abdominal circumference is associated with visceral fat (Wang et al., 2013). BMI is influenced by age, sex and ethnicity (Beydoun and Wang., 2009) and cannot distinguish visceral fat from body fat (Wang et al., 2018).

This study was consistent with a study in Mexico where women showed higher body fat percentage than men (CompeánOrtiz et al., 2018). Women exercise less and manage stress worse than men (Wang D, 2013). Women with higher estrogen associated with high BMI (Åkesson et al., 2015) so that it is significantly the cause of higher HbA1C levels (Yuan et al., 2014).

The strength of this study is to use $\mathrm{HbA1C}$ levels for determining the criteria for prediabetes. The limitation in this study was not to distinguish prediabetes samples at high risk of $\mathrm{DM}$ ( $\mathrm{HbA1C} 5.7$ to $5.9 \%)$ and the risk of low DM (HbA1C 6 to 6.4\%). Further studies need to narrow the characteristics of the research sample so that the results of the study are better. The results of this study concluded that the higher the abdominal circumference (male> $90 \mathrm{~cm}$ and women> $80 \mathrm{~cm}$ ) and age $\geq 45$ years increased the risk of prediabetes.

\section{AUTHOR CONTRIBUTION}

Cindy Lestyani Loekito collected the data and wrote the manuscript. Bhisma Murti did path analysis and interpreted data analysis. Eti Poncorini Pamungkasari suggested the materials to discuss in the manuscript.

\section{CONFLICT OF INTEREST}

We declared that there was no conflict of interest.

FUNDING AND SPONSORSHIP

No external funding.

\section{ACKNOWLEDGEMENT}

The author would like to thank the Prodia Clinic of Surakarta for giving permission to take the data.

\section{REFERENCE}

Abtahi F, Naghshzan A, Zibaeenezhad M, Heydari S, Khosropanah S, Zamirian M, Aghasadeghi K, Moaref A (2010). The relationship between body mass index andpre-diabetes in teachers residing in Shiraz-Iran 2009. Global journal of health science $8(4)$. https://doi.org/10.5539/gjhs.v8n4p95

Åkesson K, Hanberger L, Samuelsson U (2015). The influence of age, gender, insulin dose, IMT, and blood pressure on metabolic control in young patients with type 1 diabetes. Pediatr. Diabetes 16: 581-586. https://doi.org/10.1111/pedi.12219.

American Diabetes Association (2019). Classification and diagnosis of diabe- 
tes: Standards of Medical Care in Diabêtes 2019. Diabetes Care. https://doi.org.10.2337/dc19-Soo2

Beydoun MA, Wang Y (2009). Genderethnic disparity in IMT and waist circumference distribution shifts in US adults. Obes. Silver Spring Md 17: 169-176. https://doi.org/10.1038/oby.2008.492

Chen F, Guo Z, Wu M, Zhou Z, Luo W (2015). Impact of dynamic changes of waist circumference and body mass index on type 2 diabetes mellitus risk. Zhonghua Yu Fang Yi Xue Za Zhi 49: 1092-1097. https://doi.org/10.376o/cma.j.issn.0253-9624.2015.12.014

Compeán-Ortiz LG, Trujillo-Olivera LE, Valles-Medina AM, Reséndiz-González E, García-Solano B, Pérez BDA (2018). Obesity, physical activity and pre-diabetes in adult children of people with diabetes. Rev. Lat. Am. Enfermagem25. https://doi.org/10.159o/15188345.b2102.2981

Czernichow S, Kengne AP, Huxley RR, Batty GD, de Galan B, Grobbee D, Pillai A, Zoungas S, Marre M, Wood ward M, Neal B, Chalmers J (2011). Comparison of waist-to-hip ratio and other obesity indices as predictors of cardiovascular disease risk in people with type 2 diabetes: a prospective cohort study from ADVANCE. Eur. J. Cardiovasc. Prev. Rehabil. Off. J. Eur. Soc. Cardiol. Work. Groups Epidemiol. Prev. Card. Rehabil. Exerc. Physiol. 18: 312-319. htts://doi.org/10.1097/HJR.obo13e32833c1aa3

Díaz-Redondo A, Giráldez-García C, Carrillo L, Serrano R, García-Soidán FJ, Artola S, Franch J, Díez J, Ezkurra P, Millaruelo JM, Seguí M, Sangrós J, Martínez-Candela J, Muñoz P, Goday
A, Regidor E (2015). Modifiable risk factors associated with prediabetes in men and women: a cross-sectional analysis of the cohort study in primary health care on the evolution of patients with prediabetes (PREDAPS Study). BMC Fam. Pract. 16. https://doi.org/10.1186/s12875-0140216-3

Han C, Liu Y, Sun X, Luo X, Zhang L, Wang B, Ren Y, Zhou J, Zhao Y, Zhang D, Liu X, Zhang M, Hu D (2017). Prediction of a new body shape index and body adiposity estimator for development of type 2 diabetes mellitus: The Rural Chinese Cohort Study. Br. J. Nutr. 118: 771-776.https://doi.org/ 10.1017/Sooo7114517002859

Kashiwagi R, Iwahashi H, Yamada Y, Sakaue T, Okita T, Kawachi Y, Iwamoto R, Saisho K, Tamba S, Yamamoto K, Watanabe T, Fuji moto T, Matsuzawa $Y$ (2017). Effective waist circumference reduction rate necessary to avoid the development of type 2 diabetes in Japanese men with abdominal obesity. Endocr. J. 64: 881-894. https://doi.org/ 10.1507/endocrj.EJ17-0113

Luo W, Guo Z, Hu X, Zhou Z, Wu M, Zhang L, Liu J (2013). 2 years change of waist circumference and body mass index and associations with type 2 diabetes mellitus in cohort populations. Obes. Res. Clin. Pract. 7: e290-296. https://doi.org/10.1016/j.orcp.2012.02.005

Mansour AA, Al-Jazairi MI (2007).Cut-off values for anthropometric vari- ables that confer increased risk of type 2 diabetes mellitus and hyper- tension in Iraq. Arch. Med.Res.38: 253-258. https://doi.org/10.1016/j.arcmed.2006. 09.014

Pandey U, Midha T, Rao YK, Katiyar P, Wal P, Kaur S, Martolia DS (2017). Anthro- 
Indonesian Journal of Medicine (2019), 4(3): 252-258

https://doi.org/10.26911/theijmed.2019.04.03.08

pometric indicators as predictor of prediabetes in Indian adolescents. Indian Heart J. 69: 474-479. https://doi.org/10.1016/j.ihj.2017.06.006

Pani LN, Korenda L, Meigs JB, Driver C, Chamany S, Fox CS, Sullivan L, D, Agostino RB, Nathan DM (2008) Effect of aging on $\mathrm{A} 1 \mathrm{C}$ levels in individuals without diabetes: evidence from the Framingham Off spring Study and the National Health and Nutrition Examination Survey 2001-2004. Diabetes Care. 31: 1991-1996. https://doi.org/10.2337/dco80577

Soewondo P, Pramono LA (2011). Prevalence, characteristics, and predictors of prediabetes in Indonesia. Med. J. Indonesia. 20: 283-294. https://doi.org/10.13181/mji.v20i4.465

Tabák AG, Herder C, Rathmann W, Brunner EJ, Kivimäki M (2012). Prediabetes: a high-risk state for diabetes development. The Lancet 379: 2279-2290. https://doi.org/10.1016/So1406736(12) 60283-9

Vijayakumar P, Nelson RG, Hanson RL, Knowler WC, Sinha M (2017). HbA1C and the Prediction of Type 2 Diabetes in Children and Adults. Diabetes Care 40: 16-21.https://doi.org/10.2337/dc16-13 $-58$.

Wahyuni N, Murbawani EA (2016). Hubungan lingkar pinggang dan rasio lingkar pinggang panggul dengan kadar serum high sensitivityc-reactive protein pada remaja yang mengalami obesitas. https://doi.org/10.14710/jnc.v5i4.1644.

Wang D, Xing XH, Wu XB (2013). Healthy lifestyles of university students in China and Influential Factors. Sci. World J. https://doi.org/10.1155/2013/412950

Wang F, Chen Y, Chang Y, Sun G, Sun Y (2018). New anthropometric indices or old ones: which perform better in estimating cardiovascular risks in Chinese adults. BMC Cardiovasc. Disord. 18. https://doi.org/10.1186/s12872-018-o 754-z

Wang J, Wang H, Liu J, Ma J. (2013). The association between body mass index, waist circumference with body fat percent, and abdominal fat rate in over weight and obese pupils. Zhonghua $\mathrm{Yu}$ Fang Yi Xue Za Zhi 47: 603-607. https:// doi.org/10.3760/cma.j.issn.02 53-9624.2013.07.006

Yanai H, Adachi H, Masui Y, Katsuyama H, Kawaguchi A, Hakoshima M, Waragai Y, Harigae T, Hamasaki H, Sako A (2018). Exercise therapy for patients with type 2 diabetes: A narrative review. J. Clin. Med. Res. 10: 365-369. https://doi.org/10.14740/jocmr3382w

Yang XY, Zhang M, Luo XP, Wang JJ, Yin L, Pang C, Wang GA, Shen YX, et al. (2016). Body mass index, waist circumference and waist-to-height ratio associated with the incidence of type 2 diabetes mellitus: a cohort study. Zhong hua Yu Fang Yi Xue Za Zhi 50: 328-333 https://doi.or/10.3760/cma.j.issn.0253 9624.2016.04.009

Yuan SP, Huang CN, Liao HC, Lin YT, Wang $Y$ (2014). Glycemic control outcomes by gender in the pay-for-performance system: A retrospective database analysis in patients with type 2 diabetes mellitus. Int. J. Endocrinol. https://doi.org/10.1155/2014/575124. 